International Research Journal of Management, IT \& Social Sciences
Available online at https://ijcujournals.us/journals/index.php/irjmis
Vol. 6 No. 1, January 2019, pages: 19 26
ISSN: 2395-7492
https://doi.org/10.21744/irjmis.v6n1.433

\title{
Demotivation and Academic Performance on First Year in University
}

\begin{tabular}{|c|c|}
\hline & $\begin{array}{l}\text { Hugo Jesus Juan Velez Pincay } \\
\text { Monica del Rocio Veliz Pincay } \\
\text { Maria Lourdes Veliz Pincay } \\
\text { Antnio Vazquez Perez }\end{array}$ \\
\hline Article history: & Abstract \\
\hline $\begin{array}{l}\text { Received: } 9 \text { July } 2018 \\
\text { Accepted: } 30 \text { November } 2018 \\
\text { Published: } 5 \text { December } 2018\end{array}$ & $\begin{array}{l}\text { This research is oriented in a theoretical debate on scientific studies related to } \\
\text { demotivation and academic performance, where the main causes are evidenced } \\
\text { that lead the student to school failure, in addition to a study on education as the } \\
\text { real evolutionary mechanism used by the human species, and on academic } \\
\text { performance as an indicator of it, emphasizing the causes that interfere in the }\end{array}$ \\
\hline $\begin{array}{l}\text { Keywords: } \\
\text { academic performance; } \\
\text { demotivation; } \\
\text { learning; } \\
\text { teaching learning; } \\
\text { teaching; }\end{array}$ & $\begin{array}{l}\text { teaching process learning highlighting as a main factor "the demotivation" of } \\
\text { university students. The research work was based on methodology of applied } \\
\text { descriptive study and field, as the most relevant results were that the main } \\
\text { causes of demotivation are: classroom climate not adequate, lack of } \\
\text { concentration, absence of techniques that facilitate the study and others such as } \\
\text { low self-esteem and preferences by teachers towards students, causes that are } \\
\text { also mentioned by some authors in their studies, coinciding with the results of } \\
\text { research conducted with teachers and students of the school of psychology. The } \\
\text { objective of this research is focused on describing the causes and level of } \\
\text { demotivation that interfere in the academic performance of students in the first } \\
\text { years of university careers. }\end{array}$ \\
\hline
\end{tabular}

2395-7492@ Copyright 2019. The Author. Published by SLOAP. This is an open-access article under the CC-BY-SA license (https://creativecommons.org/licenses/by/4.0/) All rights reserved.

\section{Author correspondence:}

Hugo Jesus Juan Velez Pincay,

MsC. en Education y desarrollo Social, Universidad Técnica de Manabí, Portoviejo, Ecuador

Email address: hvelez@utm.edu.ec

\footnotetext{
a Universidad Tecnica de Manabi, Portoviejo, Ecuador

${ }^{\mathrm{b}}$ Universidad Tecnica de Manabi, Portoviejo, Ecuador

${ }^{c}$ National College 3 de Mayo, Portoviejo, Ecuador

${ }^{\mathrm{d}}$ Universidad Tecnica de Manabi, Portoviejo, Ecuador
} 


\section{Introduction}

Many are the schoolchildren they do not know how to study, nobody teaches them how to work or study; we must learn to learn, in some it is noted that they have to make a great effort to try to assimilate a subject without knowing how to do it, this brings a poor result with the consequent discouragement on the part of the student. Turning study into a habit is one of the tools to achieve academic success, the study is a daily task, which requires constant practice, but if it is not comforting in itself, the formation of habit is more difficult and is another cause of the demotivation (Torres, 2010).

The teaching-learning process is colored by the influence of numerous psychosocial factors. The scientific literature reflects significant evidence of the influence of psycho-pedagogical and social variables such as motivation, encouragement at an early age, the level of departure and the learning strategies used. However, there are other less studied variables such as demotivation, communication skills, assertiveness, vulnerability to stress, social support among others, which also participate directly in the process.

Ruan (2018), the causes that interfere in the teaching-learning process highlighting the academic performance of university students as the main factor continue to be studied. Many have investigated fundamentally in the stimulation that the person receives or has received and in his personal learning history. For example, one can find an explanation to this question in factors such as the family as the first agent and the most constant in the formation of the characteristics individual children, but also in the conditioning of a disadvantaged social environment, the school failures that drag, among others.

Demotivation occurs when the student does not seem to have an interest in learning due to lack of academic esteem, discouragement, lack of appreciation of the effort made by both teachers and students, attribution of guilt, for the student's social context: the family, the neighborhood that gives rise to other problems such as indiscipline. Demotivation supposes the existence of limitations against which it is very difficult to fight and overcome such as low expectations and inadequate attributions, lack of habits, prejudices, lack of knowledge and skills and others in which it is difficult to obtain any change.

Studies carried out with students of the first year of the medical career, showed that the academic performance within the university is the product of the influence of multiple factors, which are evident from the first years of study; according to these studies, the majority of the students participating in the present study came from state schools, lacked study habits and strategies, had moderate to low self-esteem, had low socioeconomic status, resided in marginal urban areas, without their own home, and some had physical conditions that were detrimental to your health; all of the above could influence the low academic performance they presented (Jara et al., 2008).

Other research has also been conducted on academic performance as an indicator of the learning that students present in terms of skills and abilities, as a result of the participation of an educational situation in the field of education (Chávez \& Rojo, 2007). One of the difficulties encountered is the academic performance that may be the possible origins of demotivation are related to the effective, social, academic, studies conducted in Colombia show that academic performance has tried to be explained by the intelligence of students (Contreras, 2008). The objective of this work is to find that is the fundamental cause of demotivation in university students to complete their studies.

\section{Materials and Methods}

It is important to perform an analysis on these variables to enhance the achievements of students in the field of education and especially the case under study. The methodology used was the investigation of statistical data of the different ones, studies carried out that had an approach to the problem, virtual information, journals, texts, personal experiences, and libraries both local and UTM, nourished with fieldwork.

In the development of the fieldwork there was a planning and socialization that was agreed with the corresponding universe for its authorization and respective application, which was 6 teachers and 50 students, the technique used was observation, the survey to feed the information, an informal dialogue was applied to the professors, at every moment we had the permission of the authorities of the faculty and the respective endorsement of the highest authorities of the Technical University of Manabí (UTM), the resources used to this work was human, material (field notebook, survey sheets, pencils, eraser, and others), computer was used among the equipment. This work is considered in the nonexperimental, field research groups because it was done in the classroom and hallways where it was in the universe; and applied because it was aimed at solving a social problem. 


\section{Results and Discussions}

The demotivation according to the theoretical debate is defined as a mood disorder in which the feelings of sadness, loss, anger or frustration interfere with the daily life of the individual, in addition, problems in the educational environment such as low academic performance. According to virtual information, it has its main roots in three basic environments such as the personal affective sphere related to the family and its emotional stability, the social environment related to its environment and the educational environment related to its own history of personal learning; that is, that demotivation is one of the main causes that lead the student to school failure.

As a result of the field work on the development variable in the case of demotivation, 50 students of the Psychology career were selected from them suffering from the problem a total of $76 \%$, only $24 \%$ of them do not suffer from this difficulty. In figure 1 , these results are shown.

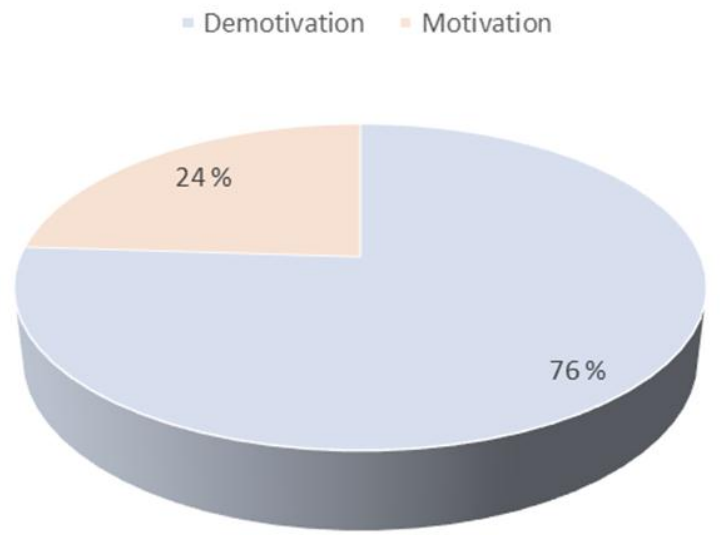

Figure 1. Percentage of students who suffer demotivation and motivation

The factors were studied, obtaining the results shown in table 1. As observed, the highest percentages are found in the economic factor and the study habit.

Table 1

Factors involved in motivation processes

\begin{tabular}{lll}
\hline Demotivation criteria & Frequency & $(\%)$ \\
\hline Family & 3 & 3,8 \\
Environment & 11 & 13,9 \\
Study habit & 15 & 19 \\
Lack of knowledge & 13 & 16,4 \\
Discipline & 2 & 2,5 \\
Economic means & 31 & 39,2 \\
Driving school failure & - & 0 \\
Prejudice & - & 0 \\
Not answering & 4 & 5 \\
\hline
\end{tabular}

A large constellation of factors related to demotivation is identified, from abandonment due to poor previous training (Zubieta et al., 2010), social origin (Rodrígez et al., 2003), low self-esteem (Masjoan, 1989), poor academic and social integration (Tinto, 1975) or other psychological characteristics such as inability to delay rewards or overcome obstacles (Landry, 2003), meanwhile students identify the economic environment as the most important with $39.24 \%$, study habits $18.99 \%$, lack of knowledge, $16.46 \%$, environment $13.92 \%$, do not answer $5.06 \%$ and the $3.80 \%$ family, coinciding previous studies with pre research.

Pincay, H. J. J. V., Pincay, M. del R. V., Pincay, M. L. V., \& Perez, A. V. (2018). Demotivation and academic performance on first year in university. International Research Journal of Management, IT and Social Sciences, 6(1), 19-26. https://doi.org/10.21744/irjmis.v6n1.433 
The most vulnerable difficulties were identified, as were the economic factors, and we investigated which were the fundamental causes in Table 2 , the results obtained are observed.

Table 2

Dependence on economic factors Economic

\begin{tabular}{lll}
\hline Factors & Frequency & $(\%)$ \\
\hline Work & 26 & 35,14 \\
It depends on the mother & 18 & 24,32 \\
Receives help from third parties & 8 & 10,8 \\
Does not need to do it & 1 & 1,3 \\
It depends on the father & 15 & 20,2 \\
Others & 6 & 8,11 \\
\hline
\end{tabular}

According to the research, the students have their own financial solvency, since 35,14\% work, depend economically on the mother $24,32 \%$, depend on the father $20,27 \%, 10,81 \%$ depend on third parties, other $8,11 \%$ and $1,35 \%$ do not need to do it, as most of the students are economic dependents this is a cause of serious conflicts related to family and education.

The forms of demotivation that are present in the psychology students of the Technical University of Manabí, $35.84 \%$ mention other factors, $18.87 \%$ did not answer, $16.98 \%$ cost me, I hate such a subject 13 , $21 \%$, not studying $7.55 \%$, I have failed too many times $5.66 \%$ and I do not like teachers in the order of $1.89 \%$. According to what has been analyzed, we can observe that the most demotivating form of the case under study are other forms such as the techniques and absences of the teachers and other factors of lesser relevance in the statistical order.

Students want to learn but lose interest when they perceive that they are not progressing at the same pace as their peers and that they obtain poor returns. These experiences could generate depression, demotivation, insecurity, stress, anxiety, frustration or awaken in students doubts about their own ability.

Psychology students suffer stress in $33.33 \%$, followed by $17.24 \%$ of depression, insecurity $13.79 \%$, doubts about their own capacity $12.64 \%, 11.49 \%$ suffer from melancholy, 6, 90\% suffer from anxiety, frustration $3.45 \%$, and other $1.45 \%$, these data are related to studies previously done, these results are shown in figure 2.
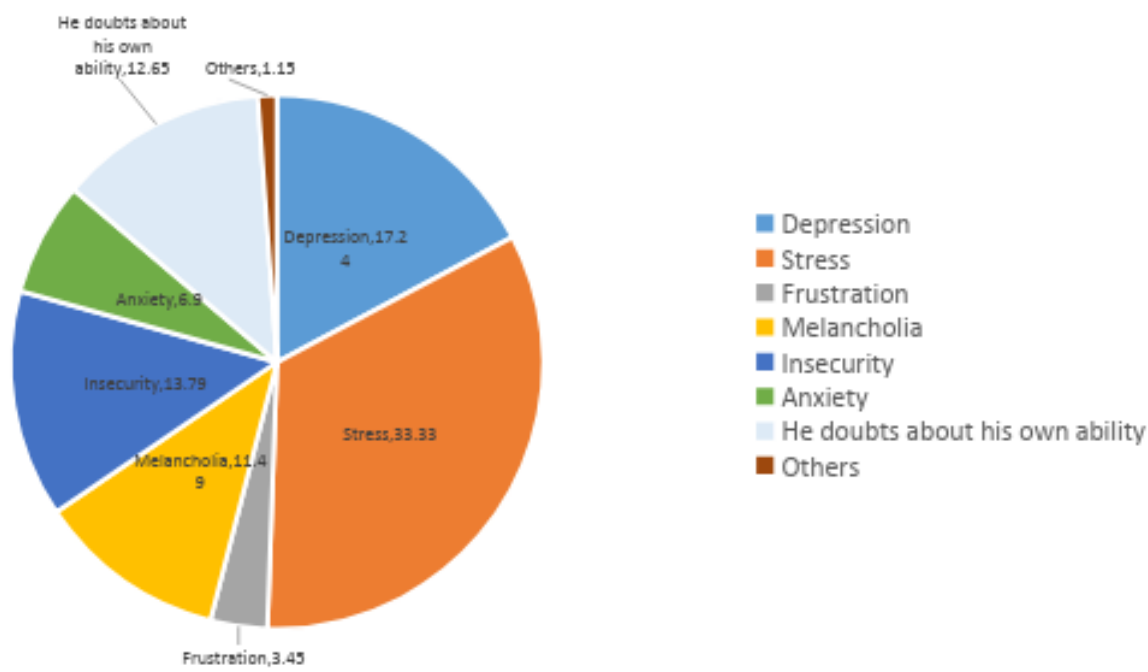

Figure 2. Demolition alternatives

Motivation, demotivation, intrinsic factors and extrinsic are part to determine and execute the most appropriate teaching and learning paradigms in the classroom, paradigms that are not the panacea but are models that serve to carry out the teaching-learning task that is to make men better for them they and their family and society in general, in this sense the Technical University of Manabí has a department in charge of training teachers continuously and 
permanently; but also must be guided by the teacher different activities that allow to transform the pedagogical work in relation to students.

UNESCO (1995) in a document related to the change and development of higher education comments that the quality of university students depends not only on the interests of studying a specific field of knowledge but on the skills of those who completed the system In this case, the emphasis is on examining the points of entry and exit of the system, assessing the quality of the students, what they learned, what they are able to learn and how the teachers are teaching.

University students must be in possession of certain intellectual and personal skills to have a good performance in their university studies, the individual differences in academic performance are due to three types of factors: the intellectual, the aptitude for study and personality.

In the universe studied academic performance is normal by $50 \%, 42 \%$ satisfactory, excellent and low $4 \%$ respectively, which warrants a deeper study because according to what was observed in the statistics and personal stories of teachers were other Realities Table 3 shows the academic performance factors obtained in the investigation.

Table 3

Academic performance

\begin{tabular}{lll}
\hline Factors & Frequency & $(\%)$ \\
\hline Characteristics of family members & 56 & 42.7 \\
Family members & 18 & 13.4 \\
Social & 10 & 7.6 \\
Economic & 14 & 10.7 \\
Pedagogical & 6 & 4.6 \\
Vocational & 7 & 5.3 \\
Structure of the educational system & 5 & 3.8 \\
Psychological & 8 & 6.1 \\
Physiological & 3 & 2.3 \\
Environmental & 4 & 3.05 \\
\hline
\end{tabular}

These factors make teachers apply different methods in the care of their students depending on their behavior, that is to say, that they apply the method of individual differences to improve the academic performance of the students. Another drawback of the problems and motivation are the dysfunctionality between the training provided by the secondary level and the university level, the problems linked to the development and transformation of the economic system, generating processes of inequality and inefficiency of the educational system as qualitative differentiation between educational institutions.

When it comes to assessing academic performance and how to improve it, the factors that can influence it are analyzed to a greater or lesser degree, generally considering, among others, socioeconomic factors, the breadth of the study programs, the teaching methodologies used, the difficulty of using a personalized teaching, the previous concepts that the students have, as well as the level of formal thought of them. As a result of the field work on the development variable, in this case, "demotivation" we have that students of Psychology of the University suffer from demotivation in the order of $76 \%$ and $24 \%$ of them do not have a learning problem.

It was verified that the demotivation interferes in the academic performance of the students, of the universe studied and that the motivation does not interfere in the academic performance. The intrinsic and extrinsic factors allow to determine and execute in the classroom the most suitable paradigms, these are models that serve to carry out the teaching-learning task that is to make men better for themselves, their family and society.

In research developed by (Alejandra Balbi \& Dansili, 2010) suggests in this regard, that learning difficulties can cause emotional problems, making the latter the most obvious. In general, students want to learn but lose interest when they perceive that they do not progress at the same rate as their peers and that they obtain poor returns. These experiences could generate depression, demotivation, insecurity, stress, anxiety, frustration or awaken in students doubts about their own ability.

Within the research, it was also detected that there are other extra-classroom factors that discourage students such as family problems, lack of knowledge, lack of study habit, the environment, and lack of work, which causes stress, depression, insecurity, and melancholy. Due to the nature of the work, a broader project is needed to know in depth the relationship between demotivation and academic performance, we must continue to investigate deeply some cases

Pincay, H. J. J. V., Pincay, M. del R. V., Pincay, M. L. V., \& Perez, A. V. (2018). Demotivation and academic performance on first year in university. International Research Journal of Management, IT and Social Sciences, 6(1), 19-26. https://doi.org/10.21744/irjmis.v6n1.433 
that have demotivation problems and those of academic levels under study that apparently have no relationship with the data obtained.

In this task the state must promote and consolidate an educational policy of scientific and technological development to motivate students and leave their state of conformity, continuing to make improvements in the educational system in their plans and programs of study, in order to achieve favorable results in the teaching-learning process and in this way obtain products of competitiveness and quality. Teachers should include in their curricular plans as a transverse axis the socialization of values, updated and participatory techniques, mysticism and human quality.

That the Admission, leveling and orientation department create support networks to work with the students who present these problems in the Institution and, as a way of prevention, apply certain tests to detect the aptitudes of young people and exclude low academic levels, desertion, changes of career and the extension of their years of study. That the students and professors participate in workshop seminars both motivation and human relations, with the aim of strengthening their self-esteem, achieve emotional balance and at the same time trigger safety, affection, enthusiasm, interest, and acceptance. With the application of these educational policies, these threats will be counteracted, converting them into strengths in order to obtain competitive professionals according to the new demands of this globalized world.

\section{Conclusion}

The empirical data obtained are fundamental to affirm that the causes that demotivate the students are: the classroom climate, the absence of teachers, the absence of study techniques, lack of concentration, and the media; among other.

\section{Conflict of interest statement and funding sources}

The authors declared that they have no competing interest. The study was financed by.

\section{Statement of authorship}

The authors have a responsibility for the conception and design of the study. The authors have approved the final article.

\section{Acknowledgments}

We would like to thank the reviewer and editor for their valuable time, support and advice. 


\section{References}

Alejandra Balbi, \& Dansili, S. (2010). Learning difficulties of the calculation: Contributions to the psychopedagogical diagostico. Pedagogical Sciences, IV (1), 7-15.

Contreras, K., Caballero, C., Palacio, J., \& Pérez, A. M. (2008). Factors associated with academic failure in university students of Barranquilla (Colombia). Psicología desde el Caribe, (22), 110-135.

Cornejo Chávez, R., \& Redondo Rojo, J. M. (2007). Variables y factores asociados al aprendizaje escolar: una discusión desde la investigación actual. Estudios pedagógicos (Valdivia), 33(2), 155-175.

Jara, D., Velarde, H., Gordillo, G., Guerra, G., León, I., Arroyo, C., \& Figueroa, M. (2008, September). Factores influyentes en el rendimiento académico de estudiantes del primer año de medicina. In Anales de la Facultad de Medicina (Vol. 69, No. 3, pp. 193-197). UNMSM. Facultad de Medicina.

Juan Carlos Zubieta, \& Susinos, T. (2010). The satisfactions and dissatisfactions of the teachers. Ducative context Education Magazine (13). http://dx.doi.org/10.18172/con.624

Rodríguez, S., Fita, E., \& Torrado, M. (2004). El rendimiento académico en la transición secundariauniversidad. Revista de educación, 334(1), 391-414.

Ruan, X. (2018). Engagement and negotiation: Exploring a tertiary female EFL teacher's professional agency in her career development in PR China. International Journal of Linguistics, Literature and Culture (IJLLC), 4(3), 4663.

Torres, M. (2010). Factors of demotivation outstanding in Learning: The affectivity inescapable requirement. Atas CIAIQ2016, Qualitative Investigation in Education // Qualitative Research in Education // Volume 1.

Unesco. (1995). Documentos de política para el cambio y el desarrollo en la educación superior. Unesco.

Pincay, H. J. J. V., Pincay, M. del R. V., Pincay, M. L. V., \& Perez, A. V. (2018). Demotivation and academic performance on first year in university. International Research Journal of Management, IT and Social Sciences, 6(1), 19-26. https://doi.org/10.21744/irjmis.v6n1.433 


\section{Biography of Authors}
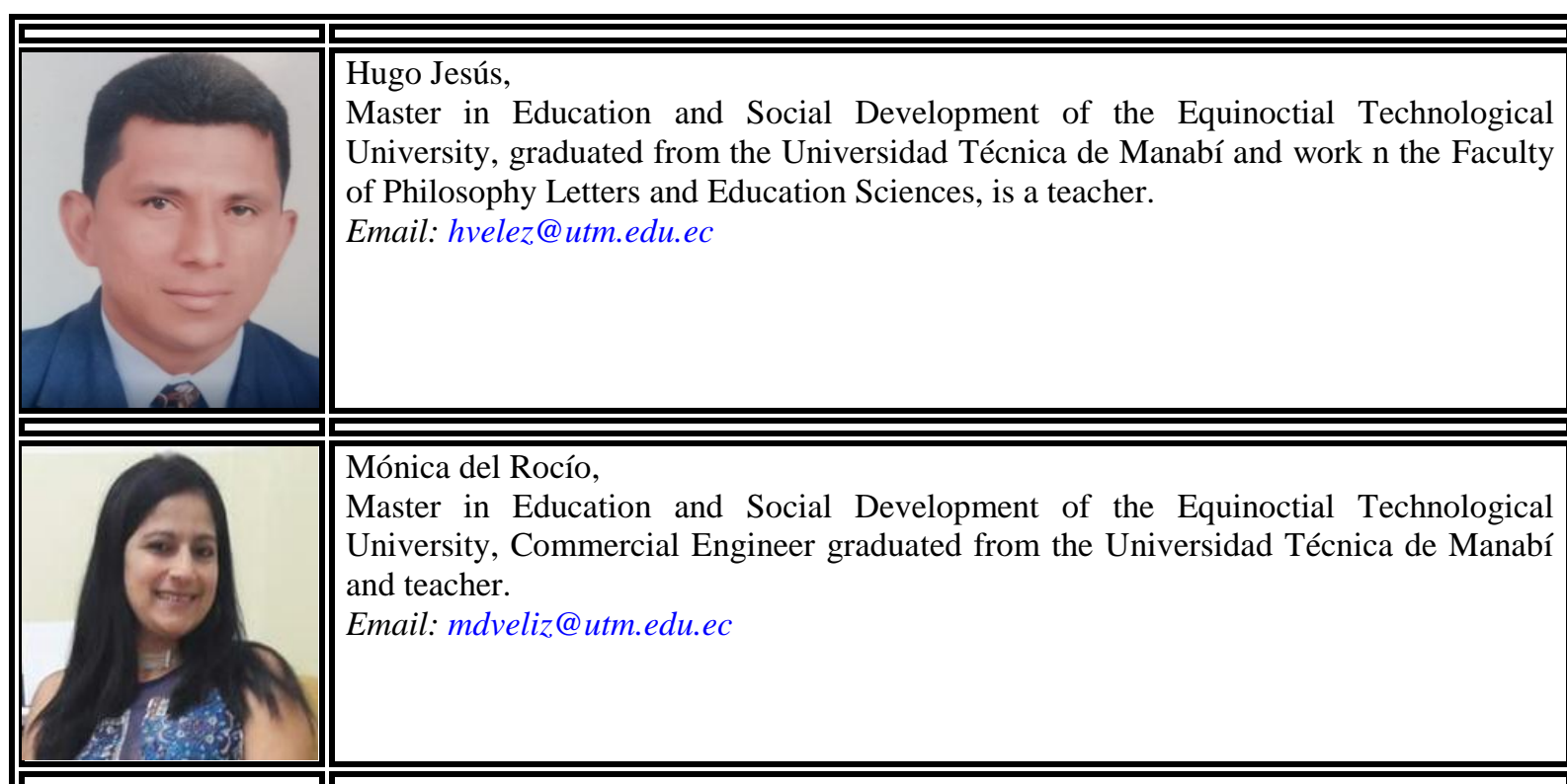

Mónica del Rocío,

Master in Education and Social Development of the Equinoctial Technological University, Commercial Engineer graduated from the Universidad Técnica de Manabí and teacher.

Email:mdveliz@utm.edu.ec

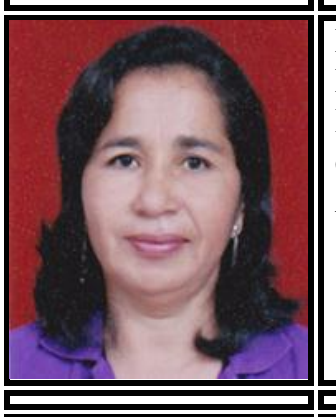

Antonio,
Lawyer, Master, a student of the doctoral program of the University of Alicante Spain,
Specialist in energy regulatory framework and local development. Actually professor of
the Faculty of Sciences, Mathematics, Physics and Chemistry, he has published more
than 30 articles, several books and participated as a invited professor and speaker at
several national and international congresses.
Email: antoniov5506@ gmail.com

